
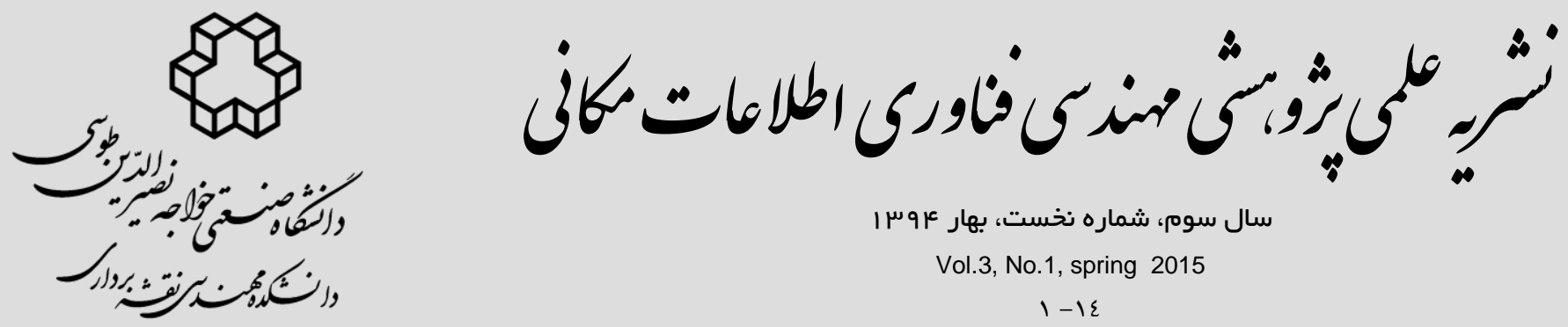

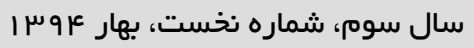

Vol.3, No.1, spring 2015

$1-1 \varepsilon$

تعيين مناطق لرزه زمين ساخت با بهكارگيرى روشهاى خوشهبندى افرازى دادههاى لرزهاى
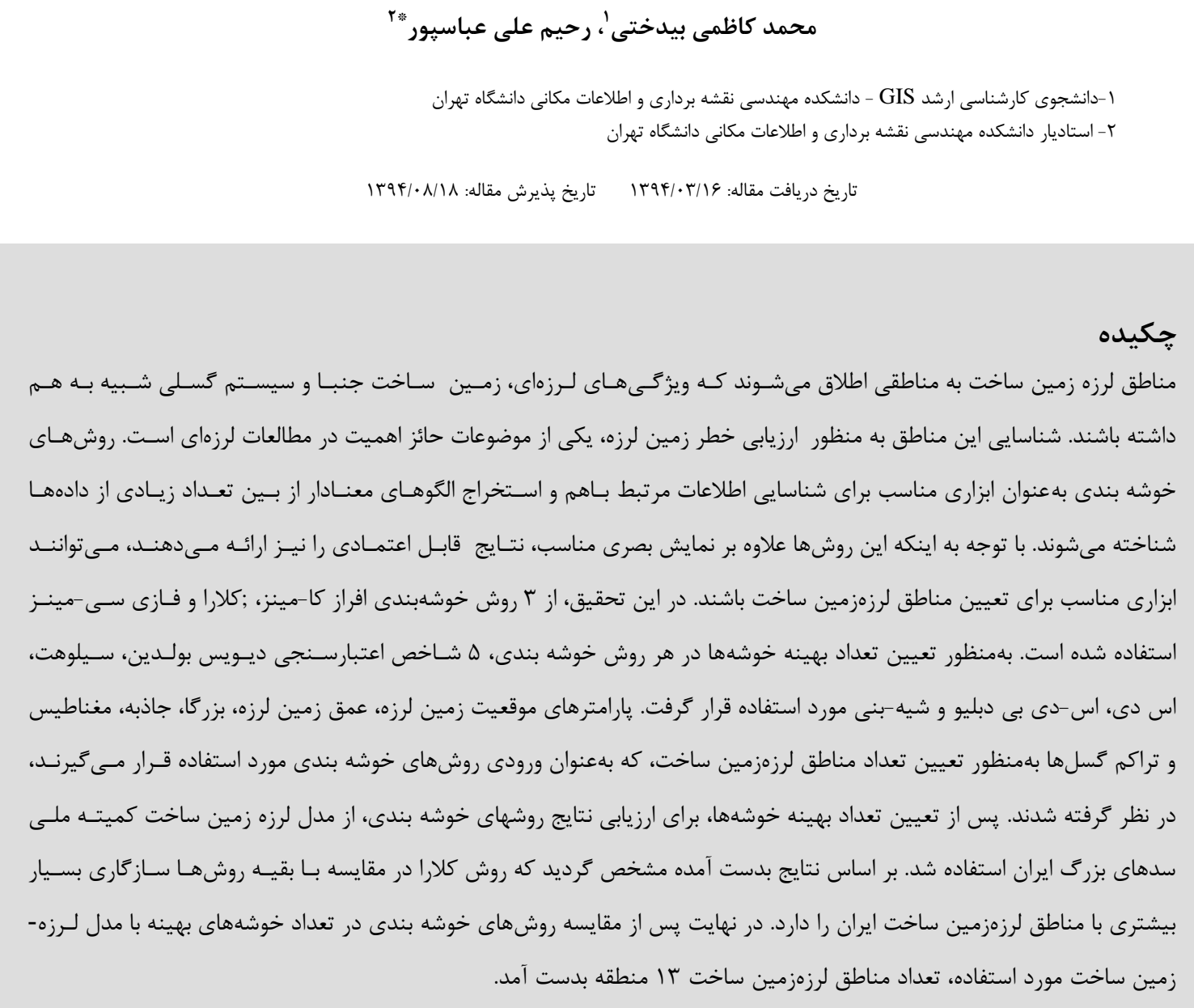

كليد وازه ها : مناطق لرزهزمينساخت ، خوشه بندى، شاخصهاى اعتبارسنجى، دادههاى زلزله.

ق*نويسنده مسئول: خيابان كاركر شمالى (اميرآباد)، يرديس دانشكدههاى فنى دانشكاه تهران، دانشكده مهندسى نقشهبردارى و اطلاعات مكانى. 
در ايران نيز بهمنظور تعيين مناطق لـرزهزمـينسـاخت،

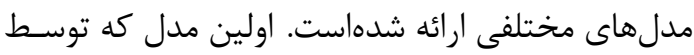

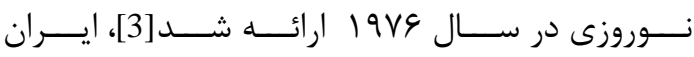

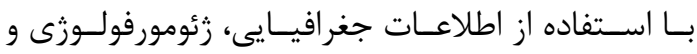

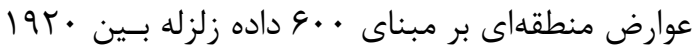

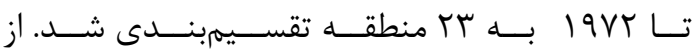
مشكلات اصلى اين مدل مى تــوان بـهـ مطالعـهـ بـر روى تعداد بسيار كمى از دادههاى لــرزهخيـزى اشـاره كـرد.

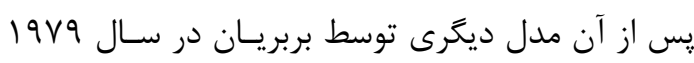

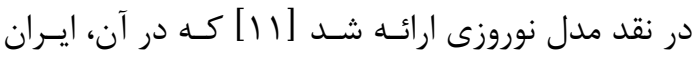

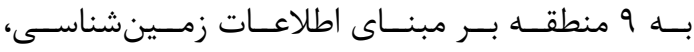

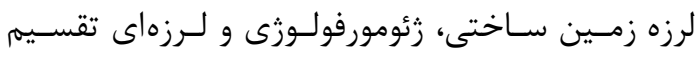

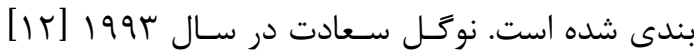

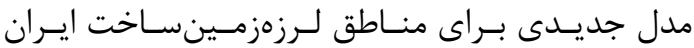

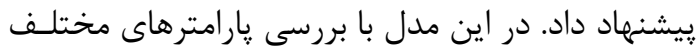

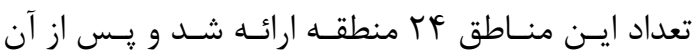

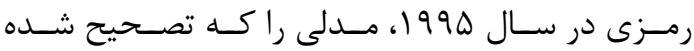

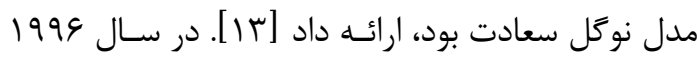

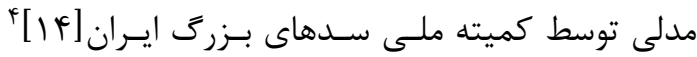

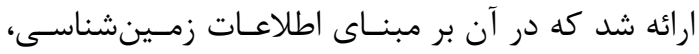

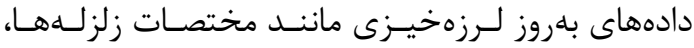

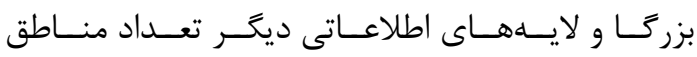

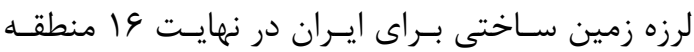

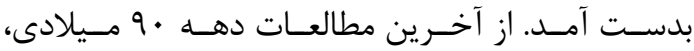

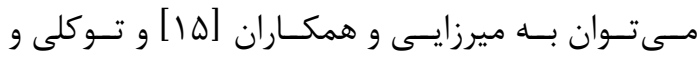

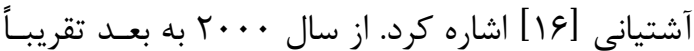
مطالعات در حوزه لرزهزمينساخت انجام نشـــ تـا سـال

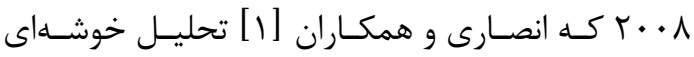

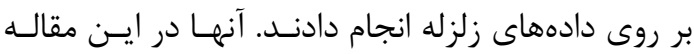
نشان دادند تحليل هاى حاصل از خوشهبندى سـاز كارى بالايى با مناطق لرزهزمينساخت دارند. در ايـن تحقيـق

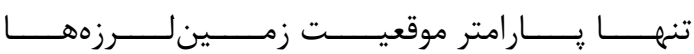

4 Iranian National Committee on Large Dams(IRCOLD)
| - 1- (- مقدمه

لرزمزمسينسـاخت ' مطالعـه ويزخى هـاى لـرزهخيـزى،

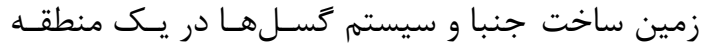

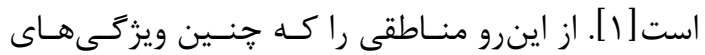

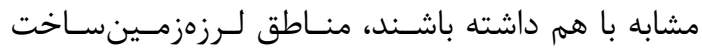

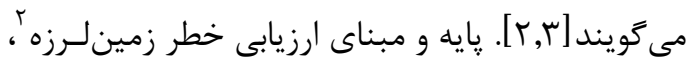

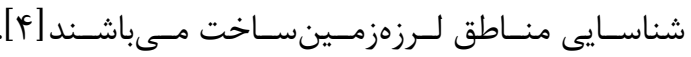
ارزيابى خطر زمينلرزه در زمينههـاى مختلفى كـاربرد

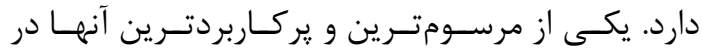

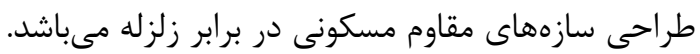

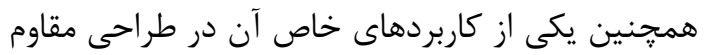

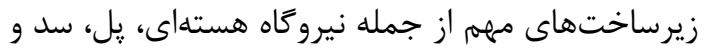

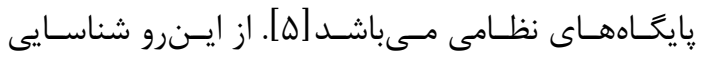

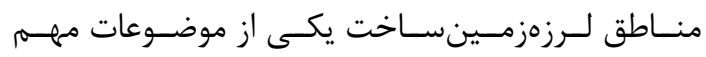
در مطالعات لرزماى مىباشد [1]. در رابطه بـا تعيسين تعـداد منـاطق لـرزهزمـينسـاخت

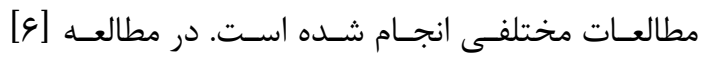

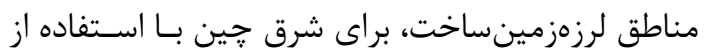

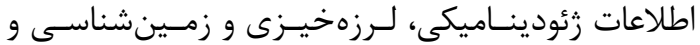

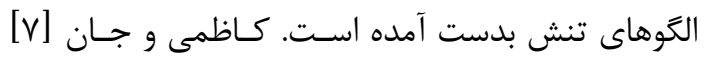

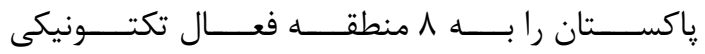

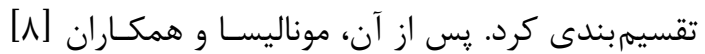

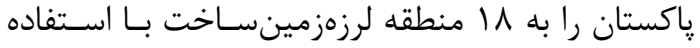

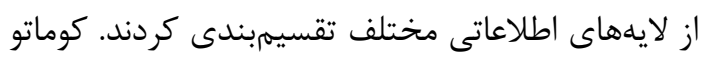

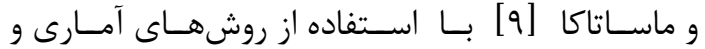

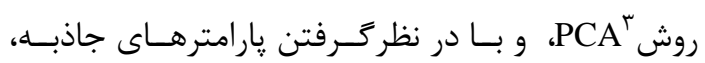

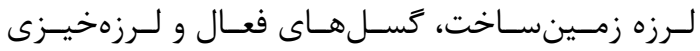

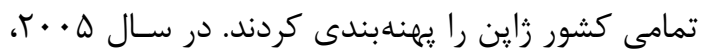
تيم تحقيقاتى USGS كشور افغانستان را بـه f أ منطقـهـ

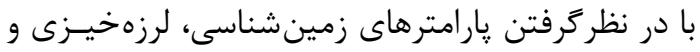
كسل هاى فعال تقسيمبندى كردند [ • [].

1 Seismotectonic

2 Seismic Hazard Assessment

3 PCA : Principle Componenet Analysis 


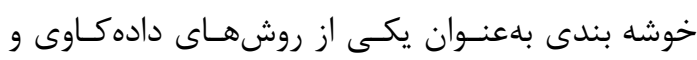

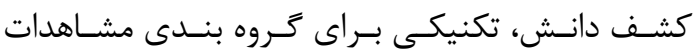

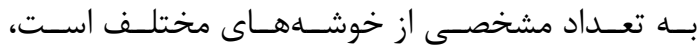
به طوريكه مشـاهدات واقع در يـك خوشـهـ بيشـترين

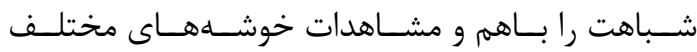

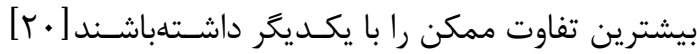
خوشهبندى كاربردهاى فراوانى در علوم مختلف از جمله

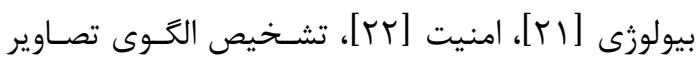

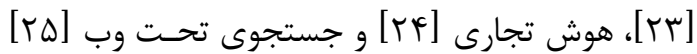

بر مبناى اينكه از خه روش خوشهبندى اسـتفاده شـود،

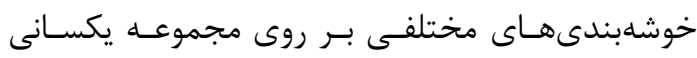

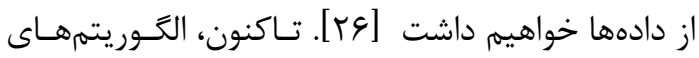

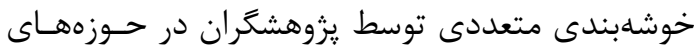

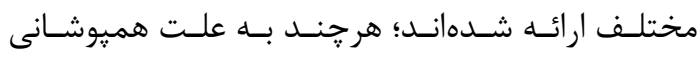
نمىتوان تقسيم بندى جامع و دقيقى از كليه روشهاى

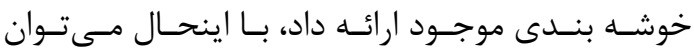

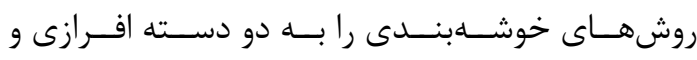

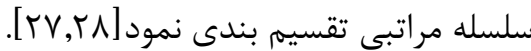

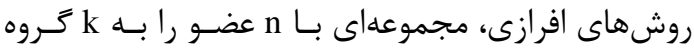

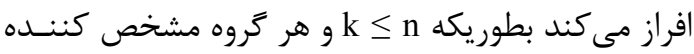

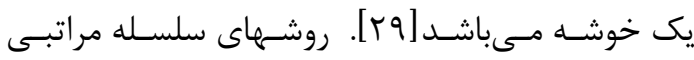

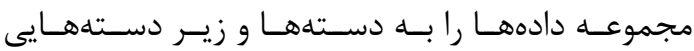
بصورت درختى تقسيمم مى كند. اين روشهــا بـهمنظــور

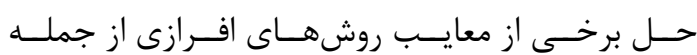

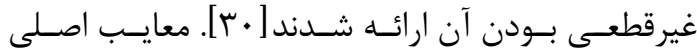

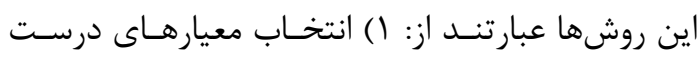

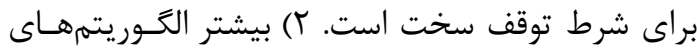
سلسله مراتبى، خوشهها را اصلاح نمسى كنــــد و مجـداد

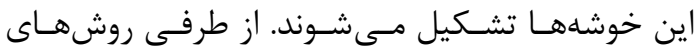

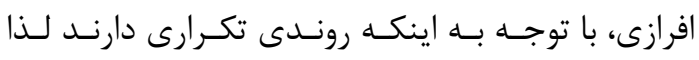

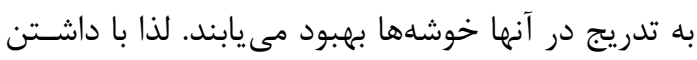

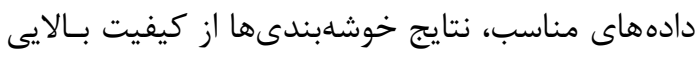
برخوردار خواهند بود. همجنين در صـورت زيـاد بـودن
در نظـر كرفتـهـ شــه اسـت و فــرض شـده اسـت كـهـ

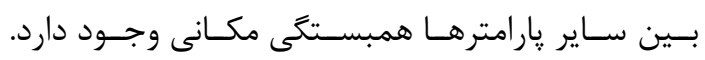

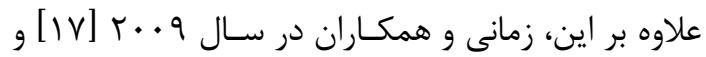

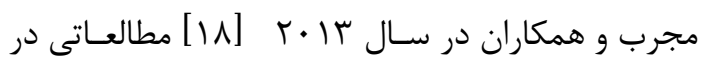

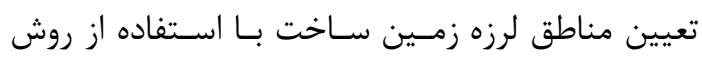

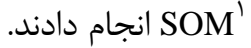

با توجه به اينكه براى ارائه هر مدل لـرزمزمـينسـاختى

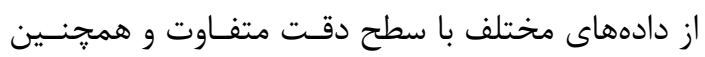

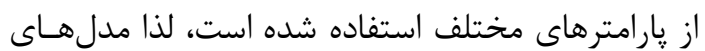

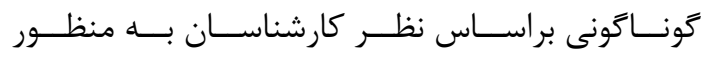

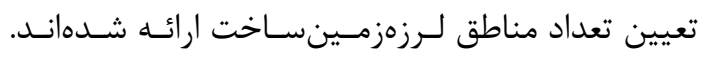

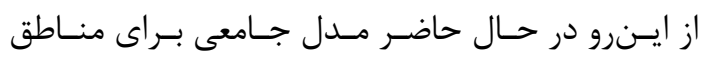

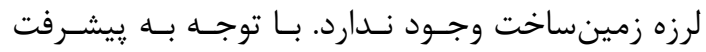

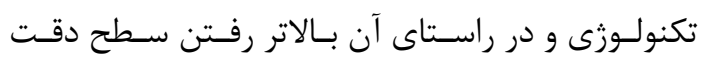

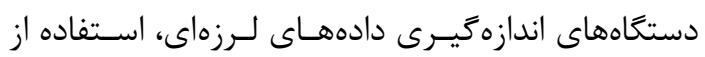

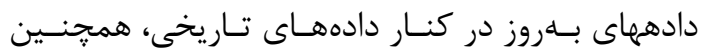

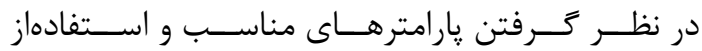

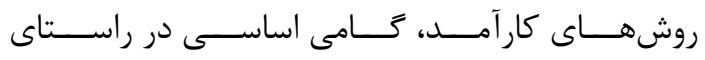
ارائه مدل جامع مناطق لرزمزمينساخت خواهد بود. داده كاوى عبارت است از استخراج اطلاعـات و دانـش و

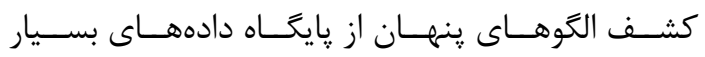

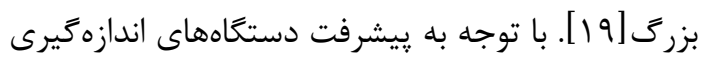

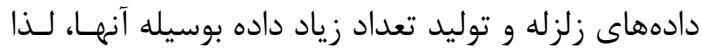

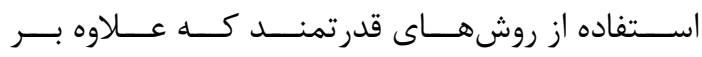

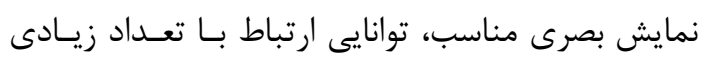

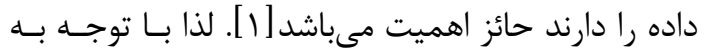
حجم زياد دادهاى لرزماى، روشهاى خوشه بندى كـهـ عـلاوه بــر نمـايش بصـرى مناسـب، توانـايى اسـتخراج

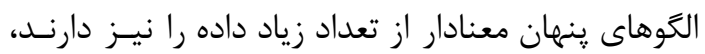
ابــزارى كـارا در تعيـين منــاطق لــززمزمــينســاخت

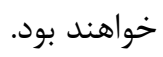

1 SOM : Self-Organizing Map 
بــهــورت خلاصــه معرفـى شــده انــد. در بخــش ؟

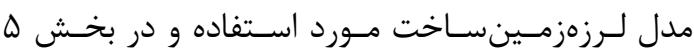
منطقه مورد مطالعه تشريح شـدهاسـت. ريـادهسـازى و ارزيابى نتايج در بخش و و در نهايست نتيجـهـيـرى در بخش V صورت گرفتهاست.

\section{r- مرورى بر خوشهبندى دادهها}

خوشابندى، يكى از شاخههاى يادگيرى بـدون نظـارت

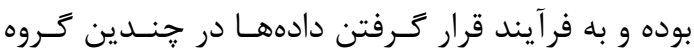

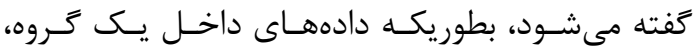
بيشترين شباهت را با هم داشته و با دادههاى گروههاى ديخر كمترين شباهت را داشته باشند.

بـــراى شــباهت مــى تـــوان معيارهـــاى مختلفــى را. در نظر گرفت. به عنوان مثال، يكىى از معيارهـا فاصـله مىباشد كه بر اساس آن نقاطى كه به يكديكر نزديكتـر هستند، بهعنوان يك خوشه در نظـر زرفتـه مسىشـوند

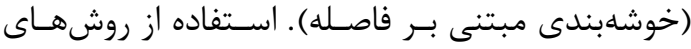
خوشهبندى متفاوت باعث ايجاد خوشههاى متفــاوت بــر

روى يك مجموعه داده يكسان خواهد شد [عr]. در ادامه ب روش خوشهبندى افرازى مـورد اسـتفاده در

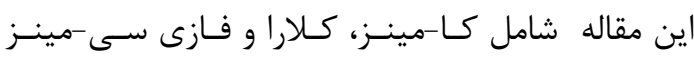
معرفى شدهاند.

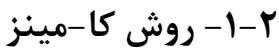

ايسن روش بــرخلاف سـادى در محاسـبات، بيشـترين استفاده را در روشهاى خوشهبندى افـرازى دارد [بسـ].

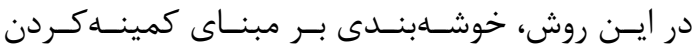
تـابع هـدف فاصـله اقليدسـى صــورت مـى كـيــرد [عب]. اين روش كه روالى تكرارى دارد، براى تعدادى ثابـت از خوشهها سعى در تخمين موارد زير را دارد: ا. بدست آوردن نقاطى به عنوان مراكز خوشهها كه

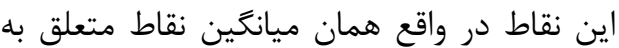
هر خوشه هستند.
تعـــداد متغيـــر هـــا، ايـــن روش نســـــت بـــهـ روش

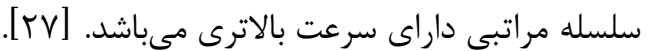
در اين تحقيق، از ب روش خوشهبندى افرازى كا-مينـز، كلارا' و فازى سى -مينز استفاده شده اسـت. روش ركـامينز، به دليل مزايايى مثل سهولت بيادهسازى، سادگى سيى و كـارايى بـالا، بـهـ طـور وســيعى مـورد اسـتفاده قــرار مى گيرد [اس].] روش كلارا در مقايسه با روش كـا-مينـز

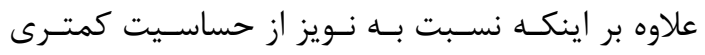

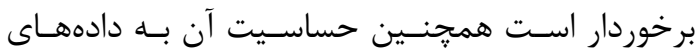

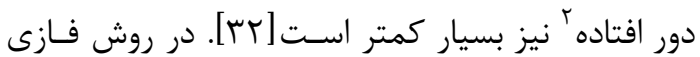
سى -مينز خوشهبندى به صورت فازى انجام مىشود. در

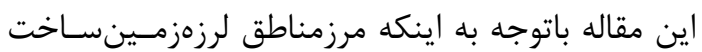

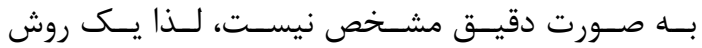
خوشه بندى فازى همانند فازى سى-مينز، كه رايجترين روش خوشهبندى فـازى محسـوب مـى شــود [سب]، نيـز

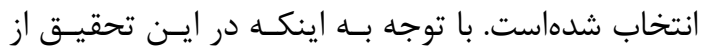
تعداد بسيار زيادى داده استفاده شدهاست لذا روشهاى مورد استفاده بايستى براى دادهها با حجـم بسـيار زيـاد

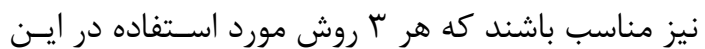
مقاله نيز اين ويزگى را دارند [اب].

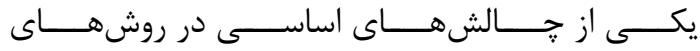

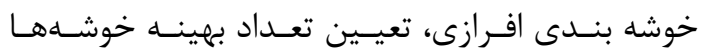

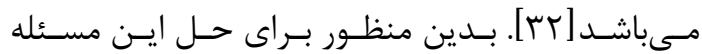

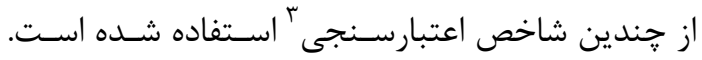

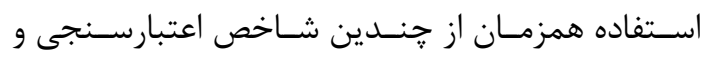

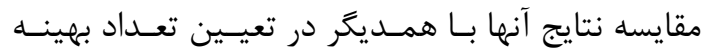

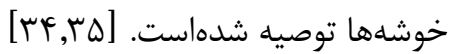
در ادامه، در بخش r مرورى بر خوشهبندى دادههـا و ه

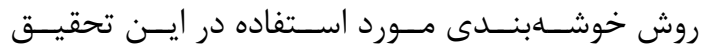
انجام شدهاست. در بخش س، شاخصهاى اعتبارسـنـى ركى

1 Clustering Large Applications

2 Outlier

3 Validity Indices 


\section{r-r- - روش فازى فازى سى -مينز}

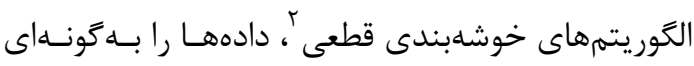

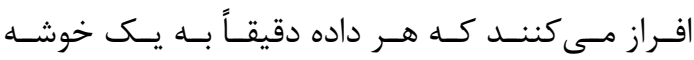

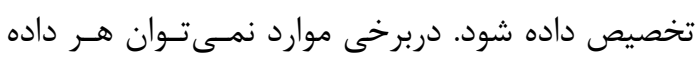

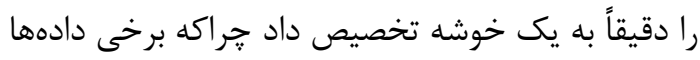

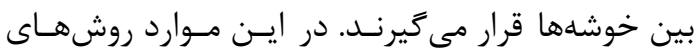

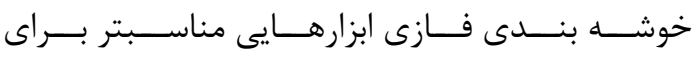

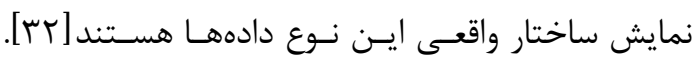
در اين تكنيك هر شى با درجه عضويتى بـه خوشـهـهـا

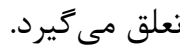
از مزايــاى ايــن روش مـــــــان بــه قابليـت هميشــهـ

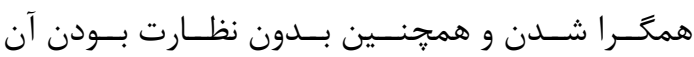

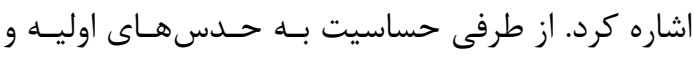
حساسيت به نويز از معايب اين روش محسوب مى شىود. اين روش كه توسعه يافته روش كا-مينز مىباشــد تـابع

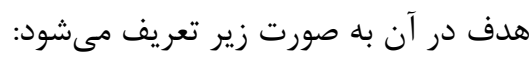
$J=\sum_{i=1}^{c} \sum_{j=1}^{n} u_{i j}^{m} d_{i j}^{2}=\sum_{i=1}^{c} \sum_{j=1}^{n} u_{i j}^{m}\left\|x_{j}-c_{i}\right\|$

رابطه (T)

در ايــن رابطـــه، خوشــه آلام، ${ }^{m}$ كفته مى شود و خوشه لآم مىباشد. همانند روش كا-مينز، در اين روش نيز به دنبال كمينه

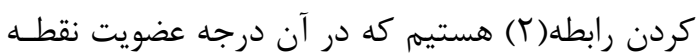

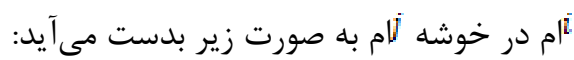
$u_{i j}=\frac{1}{\sum_{k=1}^{c}\left(\frac{d_{i j} d_{k j}}{d_{k j}}{ }^{2}(m-1)\right.}$

رابطه (؟) r. نسبت دادن هر نمونه داده به يك خوشه كه

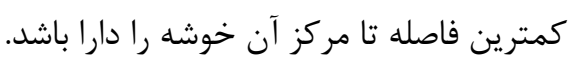
تابع هدف فاصله به صورت زير تعريف مىشود: $l=\sum_{i=1}^{e} \sum_{j=1}^{n}\left\|X_{j}^{(0)}-C_{i}\right\|^{2}$ رابطه (1) كه در اين رابطه n تعداد نقاط، ع تعـداد خوشـهـهـا،

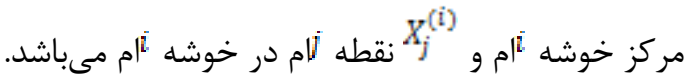

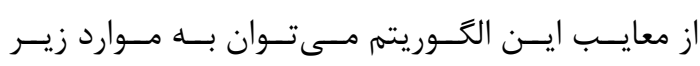
اشاره كرد [ابس]:

(Y) حساس بودن نسبت به دادههاى دور از مركز

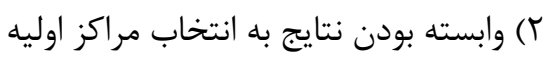

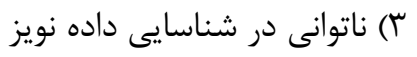

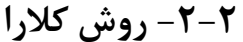

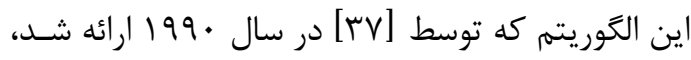

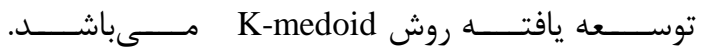
روش K-medoid بــه تعـداد تكــار زيـادى نيـاز دارد و

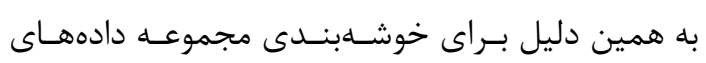
حجيم مناسب نيست. از اينرو روش كلارا معرفى شـده

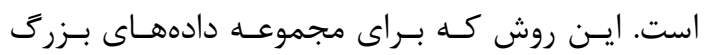

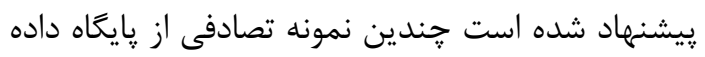

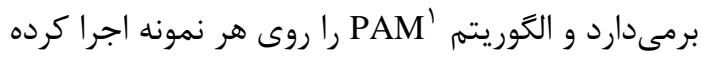
و آن نمونه را خوشهبندى مى كند. بهترين خوشهبنـدى

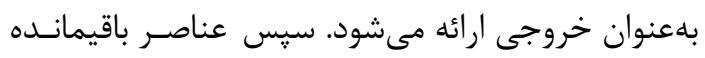

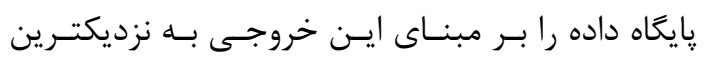

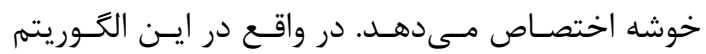

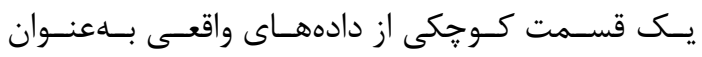

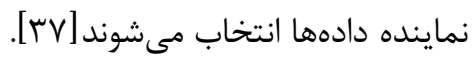


جدول ا- توضيح مختصرى از شاخصهاى اعتبارسنجى

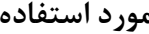

\begin{tabular}{|c|c|c|}
\hline بهينه & توضيح & شاخص \\
\hline كمترين & 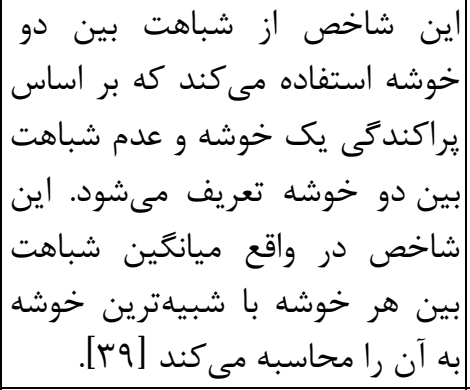 & بولدين \\
\hline بيشترين & 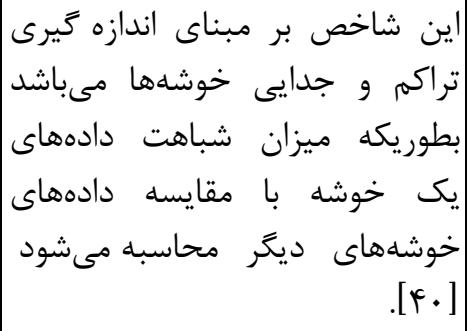 & بلوهت \\
\hline كمترين & 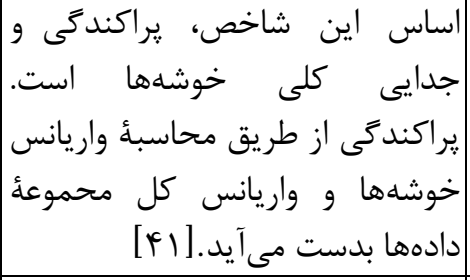 & اسدى \\
\hline كمترين & 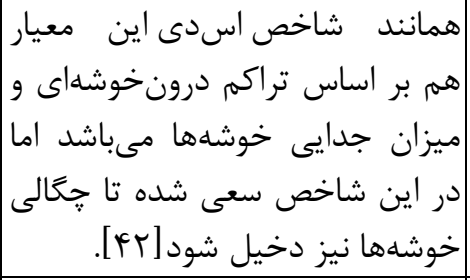 & دبلى \\
\hline كمترين & 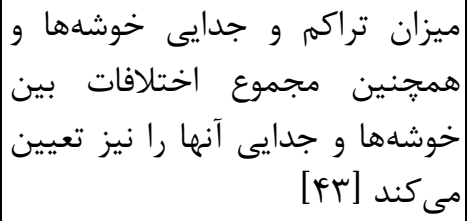 & شيه - \\
\hline
\end{tabular}

در اين تحقيق با توجه به اينكـهـ هـدف تعيـين منــاطق

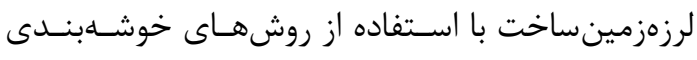

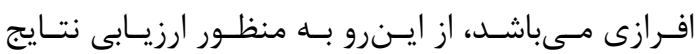
بدست آمده، بايستى خروجى هاى حاصل با مناسبترين

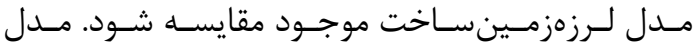

ץ- مرورى بر شاخصهاى اعتبارسنجى

يكـى از موضـوعات اساسـى در خوشــابنــدى، ارزيـابى

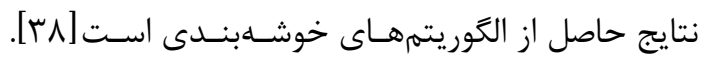

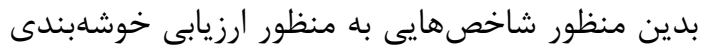

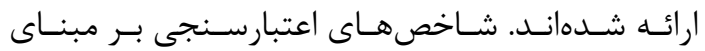
بيشترين شباهت بـين اعضـاى هـر خوشـهـ و بيشـترين تفاوت هر خوشه با خوشه هاى ديكر، محاسبه مىشـوند.

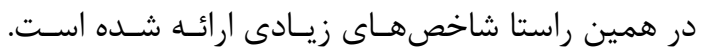

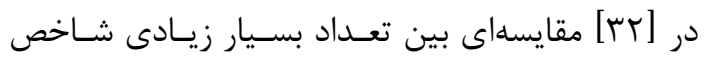

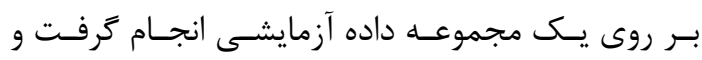

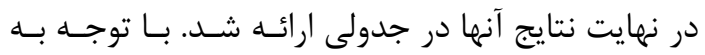

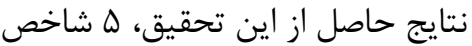

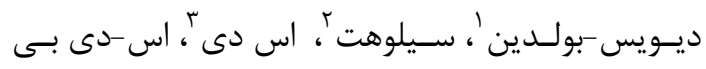

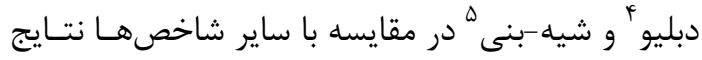

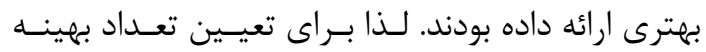
خوشـهـهــا در ايـن مقالـه از ايـن هـ شـاخص اسـتفاده

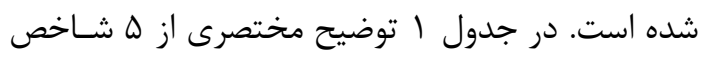

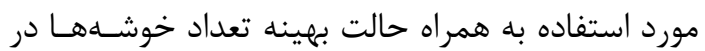
هر شاخص، آمده است.

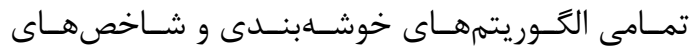
R اعتبارسنجى مورد استفاده در اين مقاله در نـرمافـزار ي يادهسازى شدهاند. ץ-مدل لرزه زمين ساخت مورد استفاده

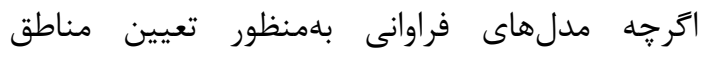
لرزه زمين ساخت ارائه شده است ولى تا به به حال مدل جامعى بدين منظور ارائه نشده است. مهمترين علل اين امر تفاوت در تعداد و دقت دادهائ مورد استفاده و همجنين تعداد يارامترهاى موثر مىباشد.

${ }^{1}$ Davies-Bouldin

${ }^{2}$ Silhouette

${ }^{3} \mathrm{SD}$

${ }^{4}$ S_Dbw

${ }^{5}$ Xie-Beni 


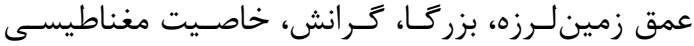

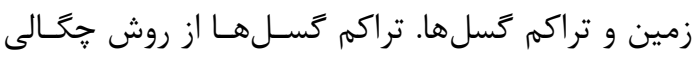

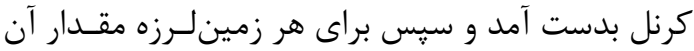

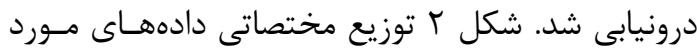

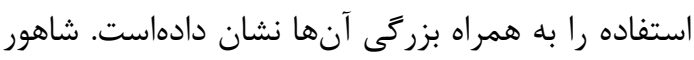
و همكاران بهمنظور تست كامل بودن دادههاى لـرزهاى، زلزلهها با بزركاى بيشتر از أ ريشتر را در نظر ترفتند.

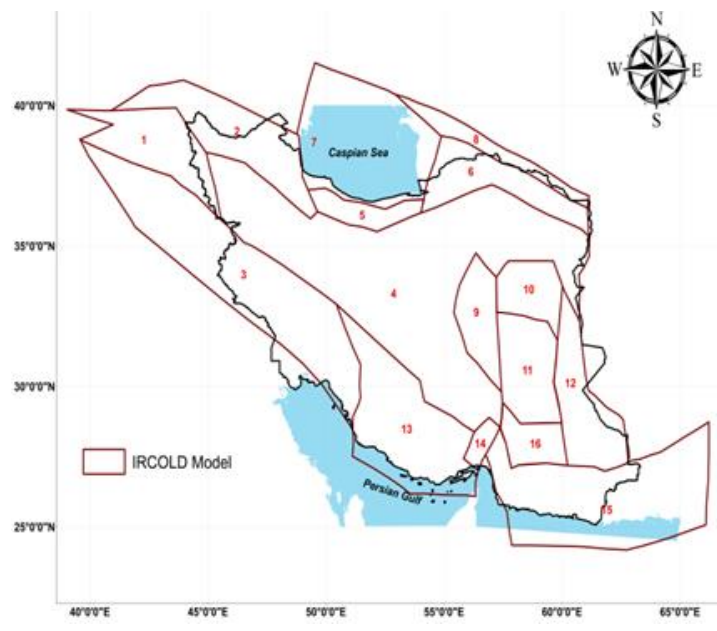

شكل ا- مدل لرزه زمين ساختى كميته ملى سدهاى بزرى ايران

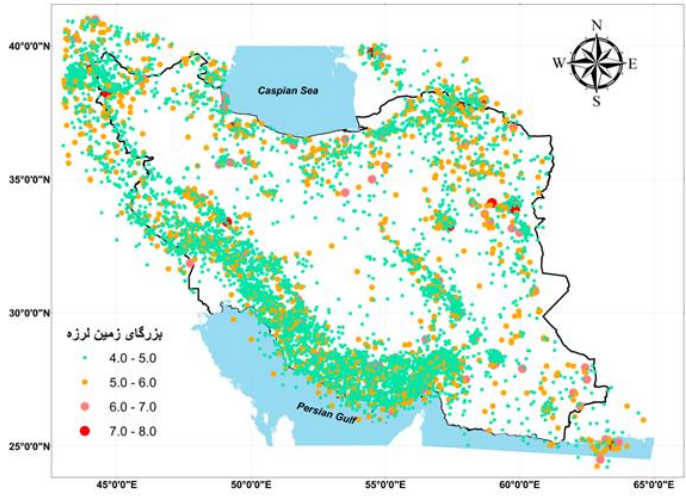

شكل r- توزيع مختصاتى دادههاى لرزهاى ايران از سال

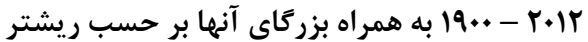

$$
\text { צ- ييادهسازى و ارزيابى نتايج }
$$

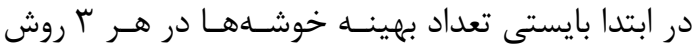

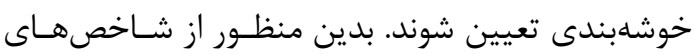
اعتبارسنجى كه در بخش ب اشاره شد استفاده مىشود.
لرزه زمين ساختى كه در اين مقاله استفاده شده اسـت،

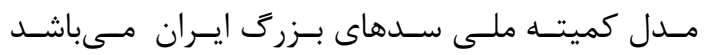
(شكل (). اين مدل عـلاوه بـر اينكـهـ جـزء جديـدترين

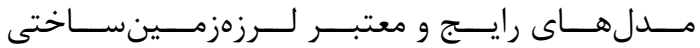

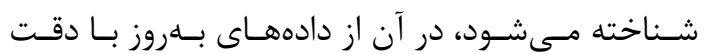
مناسب به همراه دادهاى تاريخى اسـتفاده شـدهاسـت.

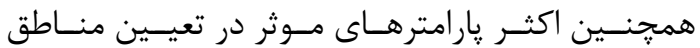

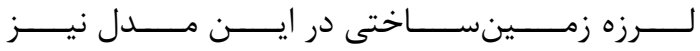

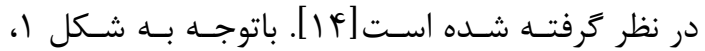
تعداد مناطق لرزهزمينسـاخت ايـران در ايـن مــل 19

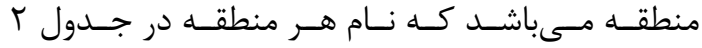

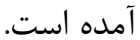

جدول r - اسامى مناطق لرزهزمين ساخت مدل كميته ملى سدهاى بزرى ايران

\begin{tabular}{|c|c|c|c|}
\hline |شمطاره & |نام منطقه & | منطقـماره | & نام منطقه \\
\hline 9 & طبس & 1 & آذربايجان غربى \\
\hline $1 \cdot$ & |فردوس & r & آذربايجان شرقى \\
\hline 11 & |لوت & r & شمال غربى زاگرس \\
\hline IT & |نهبندان & f & مركز ايران \\
\hline$\pi$ & |جنوب شرقى زاكرس & $\Delta$ & البرز \\
\hline 14 & خور & 4 & كويه داغ \\
\hline 10 & |ماركان & $V$ & جنوب درياى خزر \\
\hline 19 & جازموريان & $\Lambda$ & شمال كويه داغ \\
\hline
\end{tabular}

ه- دادههاى مورد مطالعه

در اين مقاله، از كاتالوَى لـرزهاى جـامع و همخَنـى كـهـ

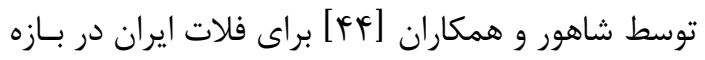

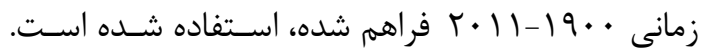
در اين تحقيق به منظور تعيين مناطق لرزهزمينساخت

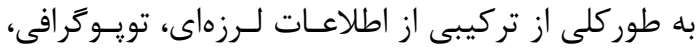
زئوفيزيك و زمينشناسى با توجه به مطالعـات ييشـين انجام شده در اين حوزه استفاده شدهاست. در اين راستا

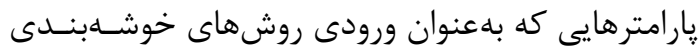

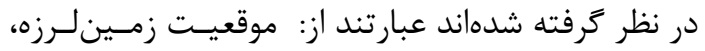


لرزه زمين ساخت كه در بخش r معرفى شـد، مقايسـهـ

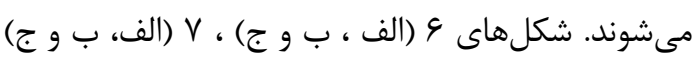

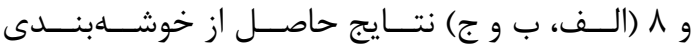
روشهاى كا-مينز، كـلارا و فـازى سـى -مينـز براسـاس تعداد خوشههاى بهينه بدست آمده به همراه مدل لرزه-

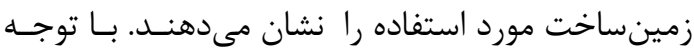
به اين اشكال، هر منطقه لرزهزمــينسـاخت بـهـ صـورت مجزا با خروجى حاصـل از روشهـاى خوشـهبنـدى در

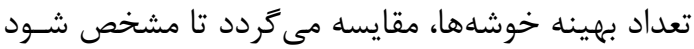
كه كدام روش سازگًارى بهترى بـا آن منطقــه دارد. بــه عنوان نمونه در روش كا-مينز در Kopt ينجم بوسيله ايسن روش شناسـايى شـده اسـت و سـاير

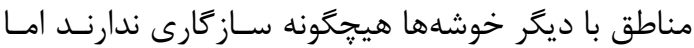
در همين روش در سا I

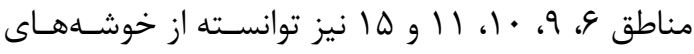
بدست آمده، استخراج كردند. به همين ترتيب اين كـار براى ديخر روشها در تمامى مها انجام مىشـود كـهـ در نهايت نتايج در جدول \& آمده است.
لازم به ذكر است كه هيج شاخصى به تنهايى نمىتوانـد براى ارزيابى خوشهبندىها مـورد اسـتفاده قـرار زيـرد.

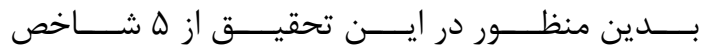

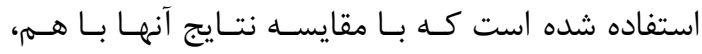
تعداد خوشههاى بهينه، كه مشـخص كنــدهى منـاطق

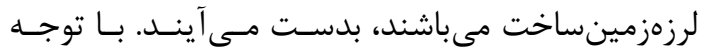

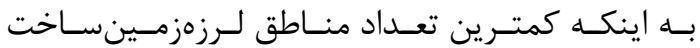
ارائه شده ه منطقه [ها]

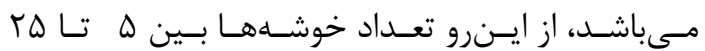

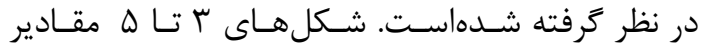
شاخصهاى اعتبارسنجى براى هر روش خوشهبندى از ه تا ها خوشه را نشان مسى دهنـد. بـا مقايسـه مقــادير

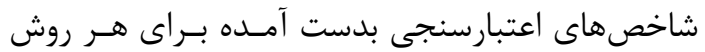

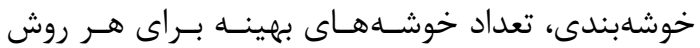
بهدست مى آيند كه در جدول r مشخص شدهاست. سيس بـه منظور ارزيابى نتايج، خوشهبنـدى باتوجـهـ بـهـ تعداد خوشههاى بهينه بدست آمده، انجـام مسى بـــود و

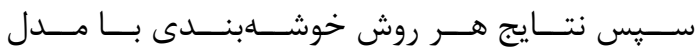
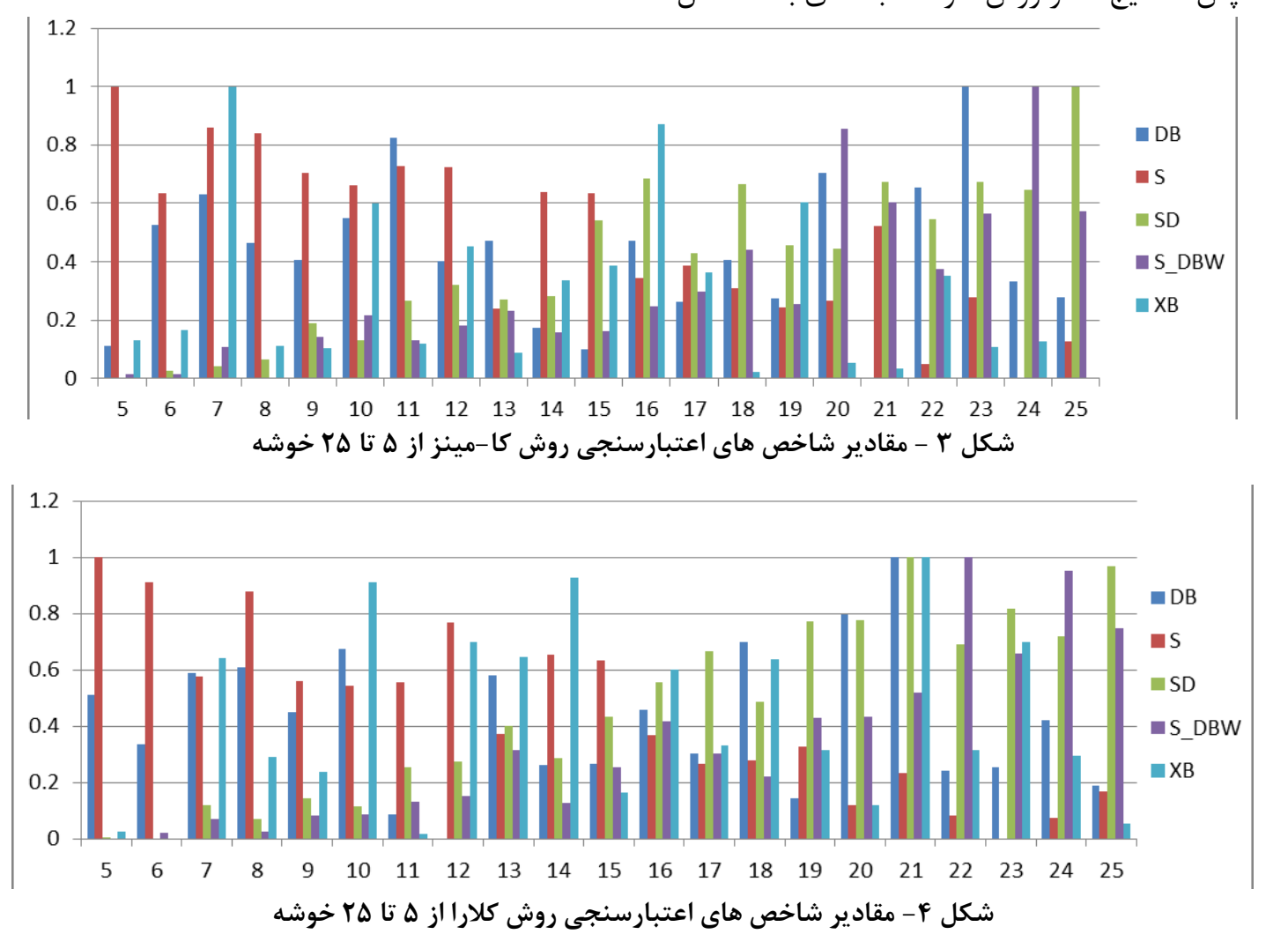


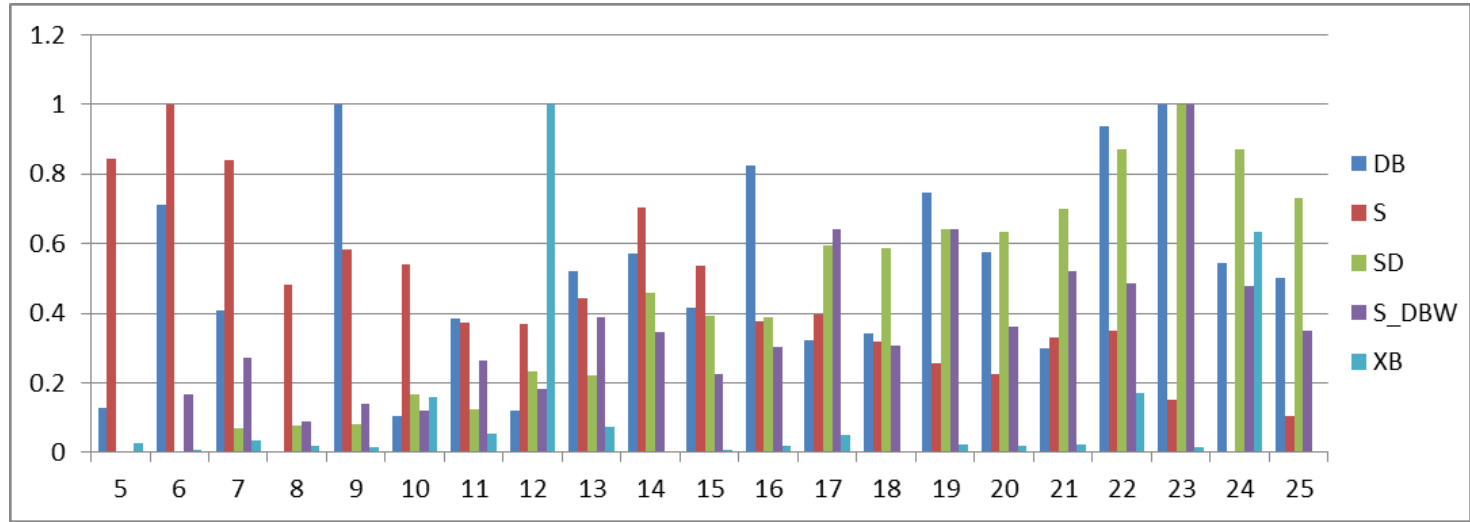

شكل ه- مقادير شاخص هاى اعتبارسنجى روش فازى سى -مينز از له تا هY خوشه جدول r - تعداد خوشههاى بهينه در هر روش خوشهبندى

\begin{tabular}{|c|c|}
\hline روش خوشهبندى & تعداد بهينه خوشهها ( \\
\hline كا-مينز & $\Lambda, 11,1 \Delta$ \\
\hline 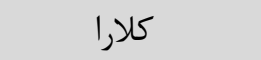 & $\Lambda,|r| r$, \\
\hline فازى سى -مينز & $q, \wedge, \mid \mathcal{F}$ \\
\hline
\end{tabular}
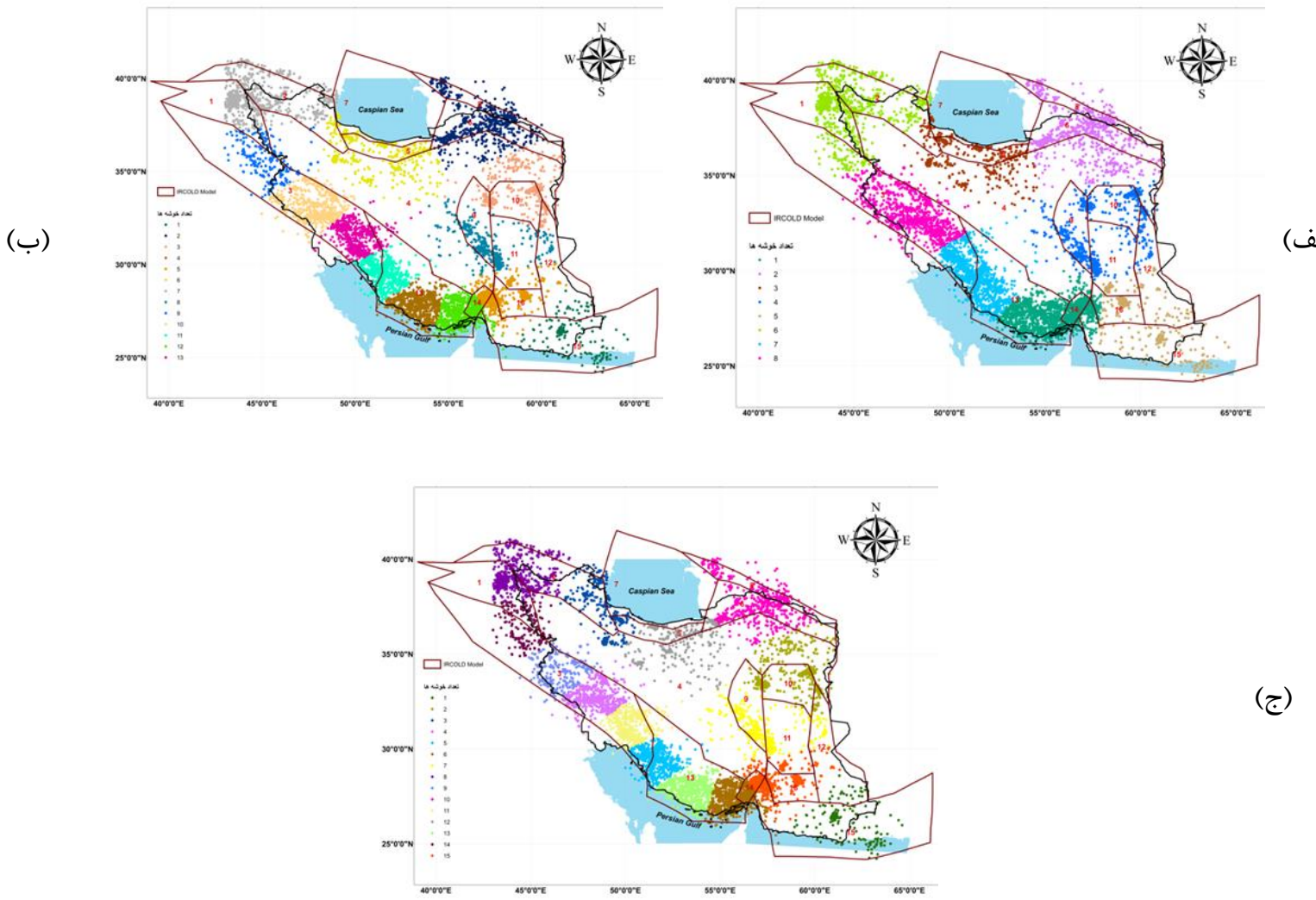

(ج)

شكل 8 الف- خوشهبندى به روش كا-مينزدر Kopt=1 , ب- خوشهبندى به روش كا-مينزدر سا=Kopt,

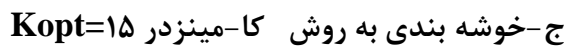


$(ب)$

$(ب)$

紫

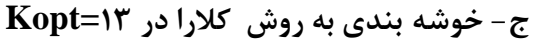
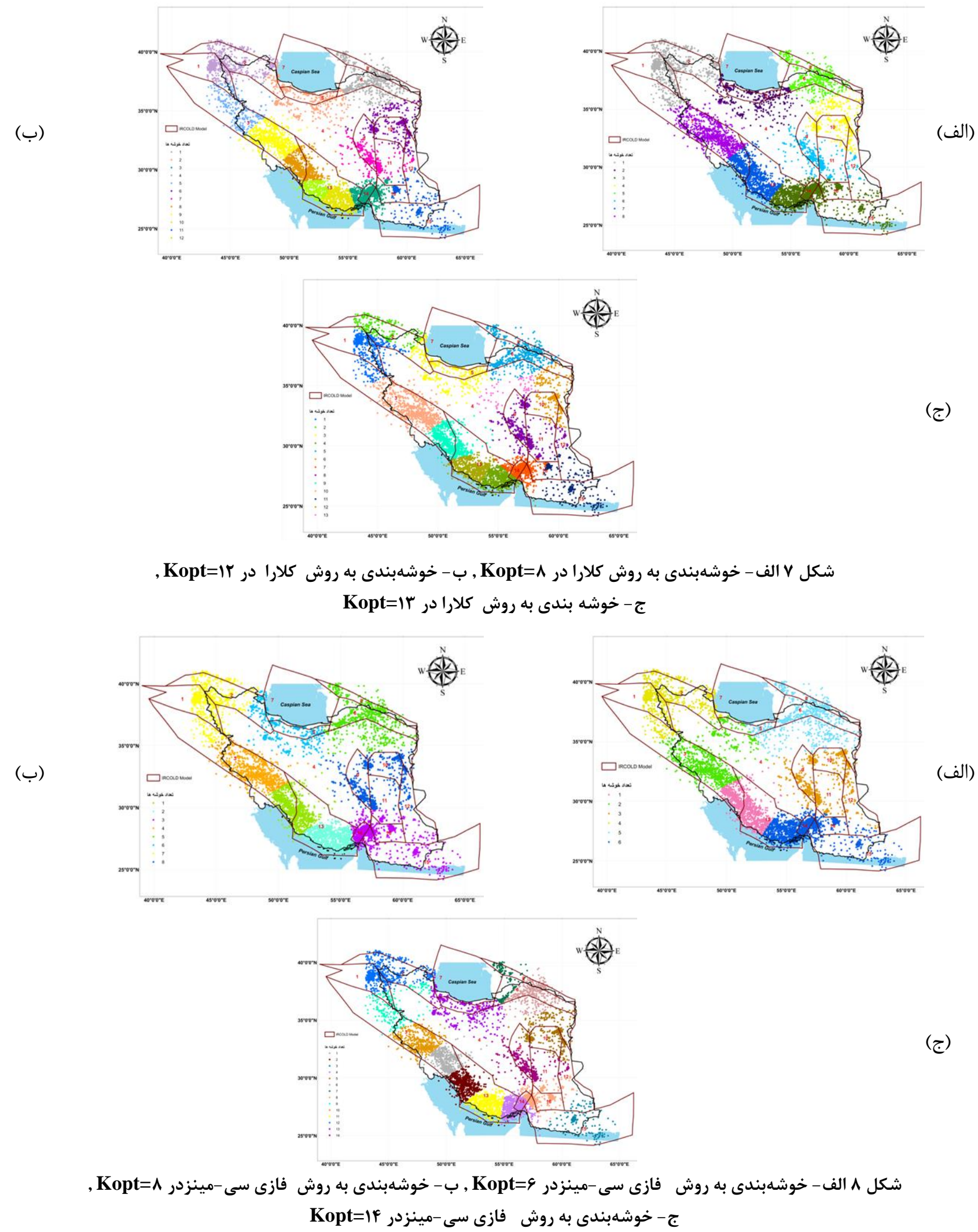

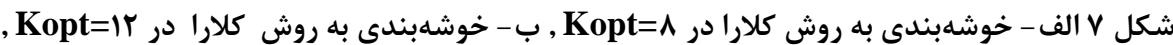


جدول f - مقايسه روشهاى خوشه بندى كا-مينز، كلارا و فازى سى -مينز در تعداد بهينه خوشهها (Kopt) با \& امنطقه لرزه زمينساخت مدل كميته ملى سدهاى بزرى ايران

\begin{tabular}{|c|c|c|c|c|c|c|c|c|c|c|c|c|c|c|c|c|c|}
\hline & $K_{\text {opt }}$ & 1 & $r$ & r & $p$ & $\Delta$ & 9 & V & $\Lambda$ & 9 & 1. & 11 & Ir & II & If & 10 & 19 \\
\hline \multirow{3}{*}{ كا-مينز } & $\Lambda$ & & & & & $\checkmark$ & & & & & & & & & & & \\
\hline & rו & & & & & $\checkmark$ & $\checkmark$ & & $\checkmark$ & $\checkmark$ & $\checkmark$ & $\checkmark$ & & & & $\checkmark$ & \\
\hline & 10 & & & & & & $\checkmark$ & & $\checkmark$ & $\checkmark$ & $\checkmark$ & $\checkmark$ & & & & $\checkmark$ & \\
\hline \multirow{3}{*}{ كلارا } & $\wedge$ & & & & & $\checkmark$ & $\checkmark$ & & $\checkmark$ & $\checkmark$ & $\checkmark$ & $\checkmark$ & & & & & \\
\hline & Ir & & $\checkmark$ & & & $\checkmark$ & $\checkmark$ & & $\checkmark$ & $\checkmark$ & $\checkmark$ & $\checkmark$ & & & $\checkmark$ & $\checkmark$ & \\
\hline & r & $\checkmark$ & $\checkmark$ & & & $\checkmark$ & $\checkmark$ & & $\checkmark$ & $\checkmark$ & $\checkmark$ & $\checkmark$ & & & $\checkmark$ & $\checkmark$ & \\
\hline \multirow{3}{*}{ 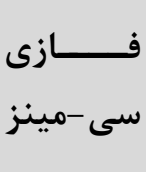 } & 9 & & & & & & & & & & & & & & & & \\
\hline & $\Lambda$ & & & & & $\checkmark$ & $\checkmark$ & & $\checkmark$ & & & & & & & & \\
\hline & If & & & & & $\checkmark$ & & & & $\checkmark$ & $\checkmark$ & $\checkmark$ & & & & $\checkmark$ & \\
\hline
\end{tabular}

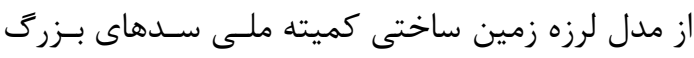

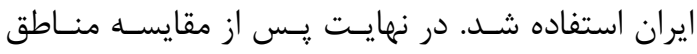

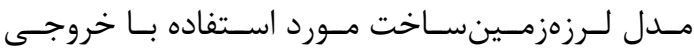

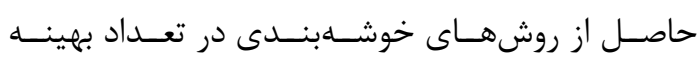

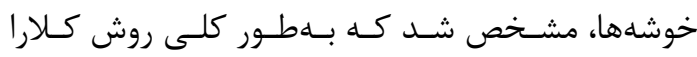
در مقايسه با دو روش ديخر سـازكارى بســيار بيشـترى

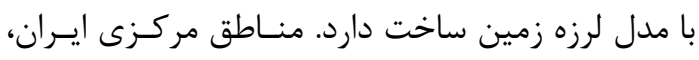

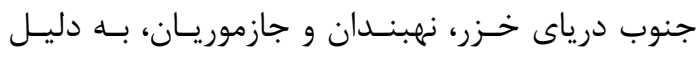

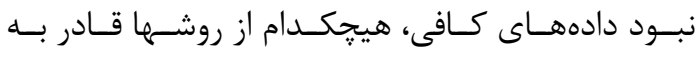

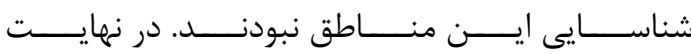

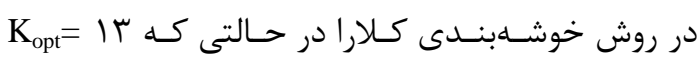
مىباشد بيشترين تعداد مناطق مدل لرزهزمــينسـاخت

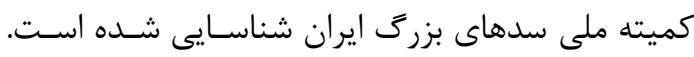

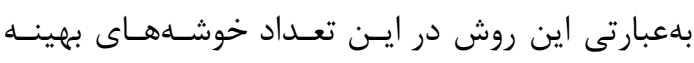

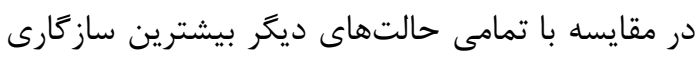

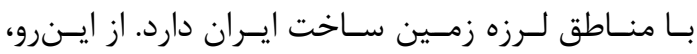

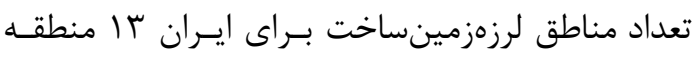
ييشنهاد مىشود.
بر اسـاس جـدول \& : ( ) روش كـلارا در مقايسـه بـا دو

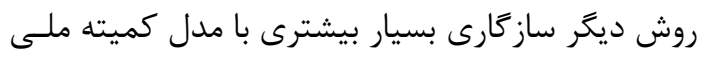

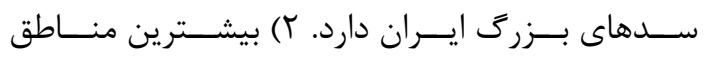

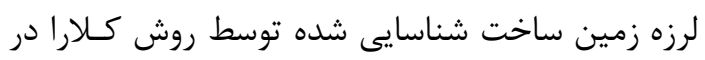

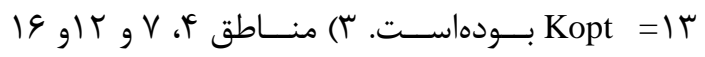
به دليل فقدان دادهاى لرزماى كافى، توسط هيجكـدام

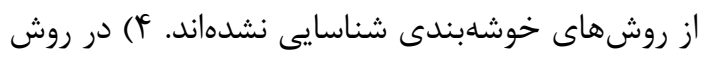

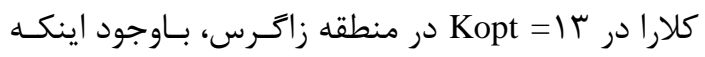

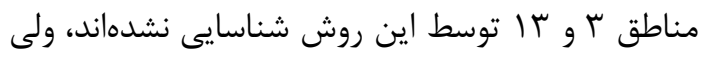

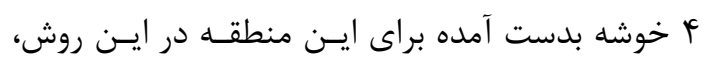

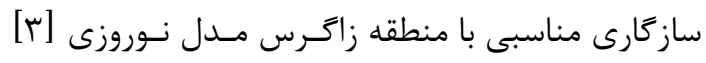

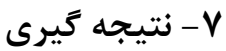

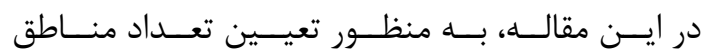

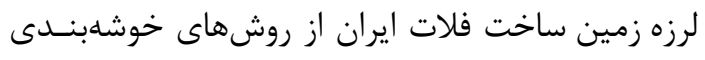

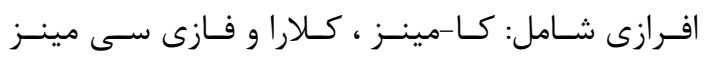

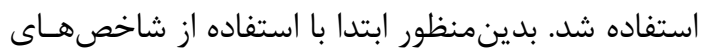

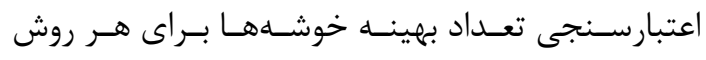

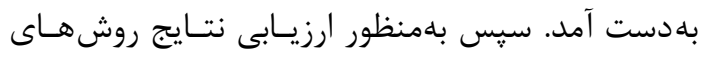

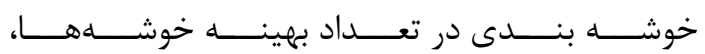


[1] A. Ansari, A. Noorzad, H Zafarani,"Clustering analysis of the seismic catalog of Iran", Computers \& Geosciences, Vol. 35, Issue 3, PP. 475 - 486,2009.

[2] M.Berberian. "Contribution to Seismotectonics of Iran (part II)" Geological Survey of Iran, Report no. 39, PP.518, 1976.

[3] A. Nowroozi. "Seismotectonic provinces of Iran", Bulletin of the Seismological Society of America, Vol. 66, No. 4, PP. 1249$1276,1976$.

[4] C.Meletti, E. Patacca, P. Scandone "Construction of a Seismotectonic model: the case of Italy". Pure Appl Geophys, Vol.157, Issue 1-2,:pp. 11-35, 2000.

[5] J.Kulgel. "Seismic hazard analysis -Quo vadis?" Earth Science Reviews, Vol.88, Issues 1-2, PP. 1-32,2008.

[6] H.Ye, G.Chen,Q. Zhou "Study on the intraplate potential seismic sources". In: Proceedings of the Fifth International Conference on Seismic Zonation, Nice, France, pp. 1424-1430, 1995.

[7] A.H.Kazmi, M.Q.Jan. "Geology and Tectonics of Pakistan”. Graphic Publishers, Karachi, vol.64,pp. 554,1997.

[8] M.Q.MonaLisa,Jan, A.A.Khwaja "A preliminary seismotectonic zonation map of the $\mathrm{Nw}$ himalayan fold-and-thrust belt, Pakistan, for the period 19042006 “. In: Proceedings of the Pakistan Academy of Science, vol. 46, pp. 175182,2009 .

[9] T.Kumamoto, T.Masataka, "Multivariate statistical analysis for seismotectonic zonation by the use of earthquake, active fault and crustal structure". Japan Geosciences Union Meeting, 2011.

[10]R.L.Wheeler， C.G.Bufe， M.L.Johnson, R.L.Dart. "Seismotectonic Map of Afghanistan, with Annotated Bibliography". U.S. Geological Survey, Open-File Report. p 31, 2005.
[11] M.Berberian. "Discussion of the paper A. A. Nowroozi, $1976 \quad$ "Seismotectonic provinces of Iran" ".Bulletin of the Seismological Society of America.vol. 69.pp. 293-297,1979.

[12] M.A.A.Nogol Sadat. "Seismotectonic map of Iran (scale 1:1 000 000)". Geological Survey of Iran, 1993.

[13] H.Ramazi. "Seismotectonic map of Iran", 1/2500000 scale, Engineering Geophysics (Ph.D. dissertation). Charles University, Prague, Czech Republic p. 100, 1995.

[14] Iranian National Committee on Large Dams (IRCOLD), "Seismotectonic province of Iran”. Report No. 12, 50 pp, 1996.

[15] N.Mirzaei, M.Gao, Y.T.Chen. "Seismic source regionalization for seismic zoning of Iran: major seismotectonic provinces". J. Earthquake Prediction Res. Vol.7,PP. 465495,1998 .

[16] B.Tavakoli, M.Ghafory-Ashtiany. "Seismic hazard assessment of Iran". Annals of Geophysics. Vol.42,PP. 1013-1021, 1999.

[17] A.Zamani, M.Nedaei, R.Boostani. "Tectonic zoning of Iran based on selforganizing map". Journal of Applied Sciences. Vol.9,PP. 4099-4114, 2009

[18] M.Mojarab, H.Memarian, M.Zare, A.H.Morshedy, M.H.Pishahang "Modeling of the seismotectonic provinces of Iran using the self-organizing map algorithm" Computers \& Geosciences, Vol. 67, PP. 150-162, 2013.

[19] G.Piatetski-Shaprio, W.J.Frawley. "Knowledge Discovery in Databases". AAAI Press/The MIT Press, Monlo Park, CA, pp. 525, 1991.

[20] L.Kaufman, P.J.Rousseeuw "Finding groups in data: an introduction to cluster analysis." JOHN WILEY \& SONS, INC. Hoboken, New Jersey, 2005.

[21] H.Shah, J.Undercoffer, A.Joshi "Fuzzy Clustering for Intrusion Detection" Fuzzy Systems. FUZZ '03. The 12th IEEE 


\section{تعيين مناطق لرزهزمينسـاخت بـا بـهـاركيرى روشهـاى ...}

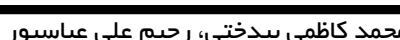

International Conference on, Vol. 2, PP. 1274-1278, 2003.

[22] J.Bezdek, L.Hall, L.Clarke. "Review of MR image segmentation techniques using pattern recognition", Med. Phys, Vol. 20, No. 4, PP.1033 -1048, 1993.

[23]J.Wang, X.Wu, C.Zhang. "Support vector machines based on $\mathrm{K}$-means clustering for real-time business intelligence systems", Int. J. Bus. Intell. Data Mining, Vol. 1, No. 1, PP.54 -64, 2005.

[24] O.Zamir, O.Etzioni. "Grouper: a dynamic clustering interface to Web search results", Proceedings of the eighth international conference on World Wide Web, Toronto, Canada, 1999.

[25]N.P.Lin, C.Chang, H.Chueh, H.Chen, W.Hao, "A deflected Grid-based Algorithm for Clustering Analysis" W. Trans. On Comp. VOL. 7, Issue 4, PP.125-132, 2008.

[26] J.Han, M.Kamber, J.Pe. "Data Mining: Concepts and Techniques ".Morgan Kaufmann Publishers, USA. 2011.

[27]P.Berkhin. "Survey of clustering data mining techniques". Technical report, Accrue Software, San Jose, CA, pp.56, 2002.

[28] A.K.Jain, M.N.Murty, P.J.Flynn. "Data clustering: a review". ACM Computing Surveys, vol.31,pp. 264-323, 1999.

[29] G.Gan, C. Ma，J. Wu. "Data clustering theory, algorithms, and applications", Society for Industrial and Applied Mathematics, Philadelphia, Pennsylvania, USA, 2007.

[30] C.A.Charu , K.R.Chandan. "Data Clustering: Algorithms and Applications ", Chapman and Hall/CRC, 6000 Broken Sound Parkway NW, Suite 300 Boca Raton, 2013.

[31]F.Hosseininezhad, A.Salajegheh "Study and Comparison of Partitioning Clustering Algorithms", Iranian Journal of Medical Informatics, Vol.2,Issue1, 2012.

[32] C.A.Charu. K.R.Chandan. "Data Clustering:
Algorithms and Applications ", Chapman and Hall/CRC, 6000 Broken Sound Parkway NW, Suite 300 Boca Raton, 2013.

[33]M.Hung, D.Yang "An efficient fuzzy cmeans clustering algorithm", Proc. IEEE Int. Conf. Data Mining, pp.225 -232, 2001.

[34]D.W.Kim, K.H.Lee, D.Lee. "On cluster validity index for estimation of the optimal number of fuzzy clusters". Pattern Recognit. Vol.37,pp. 2009-2025, 2004.

[35] A.Topchy, J.W.Punch. "Combining multiple weak clusterings". In: Proceedings of the Third IEEE International Conference on Data Mining (ICDM003), pp. 331-338, 2003.

[36] J.MacQueen. " Some methods for classification and analysis of multivariate observations "In Proceedings of the Fifth Berkeley Symposium on Mathematical Statistics and Probability, Vol. 1, PP. 281 297, Berkeley, CA, USA, 1967.

[37]L.Kaufman, PJ.Rousseeuw ."Clustering Large Applications (Program CLARA). Finding groups in data" an introduction to cluster analysis,pp.126-163, 1990.

[38]M.Halkidi, Y.Batistakis, M.Vazirgiannis. "Clustering Validity Checking Methods: Part Il." ACM SIGMODRecord, Vol. 31 Issue 2, PP. 19-27, 2002.

[39] L.Davies, L.David, L.Bouldin, W.Donald. "A Cluster Separation Measure". IEEE Transactions on Pattern Analysis and Machine Intelligence. PP. 224-227, 1979.

[40] PJ.Rousseeuw. "Silhouettes: a Graphical Aid to the Interpretation and Validation of Cluster Analysis". Computational and Applied Mathematics,vol. 20,pp. 53-65, 1987.

[41] M.Halkidi, Y.Batistakis, M.Vazirgiannis. " Quality scheme assessment in the clustering process". In PKDD, London, UK,. Springer-Verlag.pp.s 265-276, 2000.

[42] M.Halkidi, Y.Batistakis, M.Vazirgiannis. " Clustering validity assessment: Finding the optimal 
partitioning of a data set". In Proceedings of the 2001 IEEE International Conference on Data

Mining, pp. 187-194, 2001.

[43]R.Minho Kim, S.Ramakrishna. "New indices for cluster validity assessment". Pattern

Recognition Letters, vol.26,issue, 15.pp.2353-2363, 2005.

[44]M.Shahvar, M.Zare. S.Castellaro “ A unified seismic catalog for the Iranian plateau (1900-2011)" Geoscienceworld, Vol. 84 ,no. 2, pp. 233-249, 2013. 


\title{
Determination of the Number of Seismotectonic Provinces using Partitioning Clustering of Seismic Data
}

\author{
Mohammad Kazemi Beydokhti ${ }^{1}$, Rahim Ali Abbaspour ${ }^{* 2}$
}

1- MSc Student of GIS, School of Surveying and Geospatial Engineering, College of Engineering, University of Tehran 2- Assistant Professor, School of Surveying and Geospatial Engineering, College of Engineering, University of Tehran.

\begin{abstract}
Seismotectonic provinces are defined as areas that have similar seismological characteristics, active tectonic fault system similar to each other. Identification of these areas is one of the most important subjects in seismic hazard analysis. Clustering methods are known as techniques for identifying information associated with the huge number of data. Since these methods are appropriate visual representations and provide reliable results, they can be an important tool for determining the seismotectonic provinces. In this study, three partitioning clustering methods were used including: K-means, CALARA, and Fuzzy C-means. For assessing the validity of these methods, five clustering validity indexes including: Davies-Bouldin, Silhouette, SD, S_Dbw, and XieBeni were used. Parameters including the earthquake epicenters, magnitude, gravity, magnetism, and fault density, as input clustering methods, were considered for modeling seismotectonic regions. After determining the optimal number of clusters, in order to evaluate the results of clustering model IRCOLD seismotectonic model was applied. The results showed that compared with other methods, CLARA have a greater compatibility with seismotectonic model in Iran. Finally, after comparing the number of optimized clustering methods with seismotectonic model it is concluded that the best number of seismotectonic provinces is 13 .
\end{abstract}

Key words: Seismotectonic zones, clustering, validity indexes, seismic data

Correspondence : Address GIS Group, School of Surveying and Geospatial Engineering, College of Engineering, University of Tehran, Tehran, Iran. Tel : 88008841

Email : abaspour@ut.ac.ir 